\title{
Correction
}

\section{Correction: Molecular Evolution of Glycoside Hydrolase Genes in the Western Corn Rootworm (Diabrotica virgifera virgifera)}

\section{The PLOS ONE Staff}

There is an error in the affiliation for co-authors Richard ffrench-constant and Arnubio Valencia. The correct affiliations for the co-authors are:

Richard ffrench-constant - Biosciences, University of Exeter, Penryn, United Kingdom ${ }^{6}$

Arnubio Valencia - Department of Entomology, University of Nebraska-Lincoln, Nebraska, United States of America ${ }^{2}$

Departamento de Producción Agropecuaria, Facultad de Ciencias Agropecuarias, Universidad de Caldas, Manizales, Colombia $^{7}$

\section{Reference}

1. Eyun S-i, Wang H, Pauchet Y, ffrench-Constant RH, Benson AK, et al. (2014) Molecular Evolution of Glycoside Hydrolase Genes in the Western Corn Rootworm (Diabrotica virgifera virgifera). PLoS ONE 9(4): e94052. doi:10.1371/journal.pone.0094052
Citation: The PLOS ONE Staff (2014) Correction: Molecular Evolution of Glycoside Hydrolase Genes in the Western Corn Rootworm (Diabrotica virgifera virgifera). PLoS ONE 9(7): e102818. doi:10.1371/journal.pone.0102818

Published July 10, 2014

Copyright: () 2014 The PLOS ONE Staff. This is an open-access article distributed under the terms of the Creative Commons Attribution License, which permits unrestricted use, distribution, and reproduction in any medium, provided the original author and source are credited. 